\title{
Identifikasi Senyawa Asam Lemak Volatil dari Air Limbah Industri Minyak Kelapa Sawit untuk Produksi Polihidroksialkanoat oleh Ralstonia eutropha JMP 134
}

\author{
Martha Aznury ${ }^{1}$, Tjandra Setiadi ${ }^{2}$ \\ ${ }^{1}$ Teknik Kimia, Politeknik Negeri Sriwijaya, Jl. Srijaya Negara Bukit Besar, Palembang, Indonesia \\ ${ }^{2}$ Program Studi Teknik Kimia, Institut Teknologi Bandung, Jl. Ganesha 10, Bandung, Indonesia \\ Diterima : 1 Juni 2021, Revisi akhir : 15 Juni 2021, Disetujui terbit : 30 Juni 2021
}

Identification of Volatile Fatty Acids from Palm Oil Mill Effluent for Polyhydroxyalkanoate
Production by Ralstonia eutropha JMP 134

\begin{abstract}
Polyhydroxyalkanoate (PHA) is a bioplastic which is derived from bacterial fermentation. In this study, PHA is produced by utilizing Ralstonia eutroph JMP 134 and volatile fatty acids (VFA) from palm oil industrial wastewater as a precursor. The aim of this research is to study the effect of carbon source, addition time, and VFA concentration on PHA production by fermentation using Ralstonia eutropha JMP 134 in batch. PHA and dry cell weight (DCW) concentrations obtained by adding VFA from palm oil industrial wastewater in batches at 20 and 40 hours were $0.014 \mathrm{~g} / \mathrm{L}$. hour, $2.76 \mathrm{~g} / \mathrm{L}$ and $3.66 \mathrm{~g} / \mathrm{L}$, respectively. The results also showed that the time of adding VFA greatly affected cell growth, with the best addition time being after the $20^{\text {th }}$ hour.
\end{abstract}

Keywords: palm oil industrial wastewater, polyhydroxyalkanoate (PHA), batch, Ralstonia eutropha JMP 134, volatile fatty acids (VFA)

\begin{abstract}
Abstrak
Polihidroksialkanoat (PHA) adalah bioplastik yang diproses melalui proses fermentasi dengan mikroba. Pada penelitian ini, PHA diproduksi dengan menggunakan Ralstonia eutropha JMP 134 dan memanfaatkan asam lemak volatil (ALV) dari air limbah industri minyak kelapa sawit sebagai prekursor. Penelitian ditujukan mempelajari pengaruh sumber karbon, waktu penambahan, dan konsentrasi ALV terhadap poduksi PHA yang difermentasi menggunakan Ralstonia eutropha JMP 134 secara batch. Konsentrasi PHA dan berat kering sel (BKS) yang diperoleh pada penambahan ALV dari air limbah industri kelapa sawit secara batch pada jam ke-20 dan 40 masing-masing bernilai 0,014 g/L.jam, 2,76 g/L dan 3,66 g/L. Hasil penelitian memperlihatkan pula bahwa waktu penambahan ALV sangat mempengaruhi pertumbuhan sel, dengan waktu penambahan yang terbaik adalah setelah pada jam ke20.
\end{abstract}

Kata kunci: air limbah industri minyak kelapa sawit, polihidroksialkanoat (PHA), batch, Ralstonia eutropha JMP 134, asam lemak volatil (ALV) 


\section{Pendahuluan}

Ralstonia eutropha membutuhkan substrat untuk pertumbuhan dan memproduksi Polihidroksialkanoat (PHA). Pertumbuhan sel membutuhkan sumber karbon sebagai sumber energi. Sumber energi bagi perkembangan sel antara lain, glukosa dan fruktosa (Oliveira et al., 2020). Glukosa atau fruktosa selain sebagai sumber karbon juga dapat menjadi sebagai substrat dalam produksi PHA. Substrat ini dapat memproduksi salah satu jenis PHA yaitu PHB. PHA dengan jenis lainnya membutuhkan prekursor dari jenis asam lemak volatil (ALV).

Indonesia mempunyai luas area tanaman kelapa sawit 12,8 juta ha lahan. Produksi minyak kelapa sawit pada tahun 2018 adalah 27,9 juta ton (BPS, 2018). Hasil pengolahan minyak sawit ini dapat menghasilkan air limbah sekitar 83,7 juta $\mathrm{m}^{3}$. ALV alami dapat diperoleh dari air limbah industri pertanian. Hasil fermentasi anaerobik air limbah industri minyak kelapa sawit akan menghasilkan ALV (Lee et al., 2014; Chinwetkitvanich and Jaikawna, 2015). ALV ini dapat digunakan sebagai prekursor dalam memproduksi PHA (Zhang et al., 2019; Atasoy, Eyice and Cetecioglu, 2020; Patel et al., 2021; Perez-Zabaleta et al., 2021).

ALV dapat terdisosiasi dalam bentuk anion dan proton di dalam sitoplasma sel (Wang and Nomura, 2010). Hal ini akan menyebabkan terjadinya perbedaan gradien konsentrasi dengan meningkatnya jumlah proton di dalam sitoplasma. Proton ini harus dikeluarkan untuk mencegah terjadinya denaturasi komponen-komponen yang ada dalam sel. Kelebihan proton membutuhkan energi (ATP) untuk mengeluarkannya dari dalam sitoplasma. Sebagai respon akumulasi asam lemak, mikroba melepaskan energi bebas melalui ATPase. Akibatnya sel harus mengeluarkan energi untuk mengeluarkan kelebihan proton (Defoirdt et al., 2009). Dengan demikian selmengalami kekurangan atau kehilangan energi untuk pertumbuhannya. Akumulasi anion di dalam sitoplasma juga akan meningkatkan tekanan osmotik. Dengan demikian dapat memecahkan dinding sel mikroba tersebut (Tan et al., 2014). Keseluruhan faktor tersebut menyebabkan penurunan aktivitas mikroba, seperti laju penggunaan asam, laju pertumbuhan, dan yield (Koller, 2018; Meereboer, Misra and Mohanty, 2020). Gambar 1 memperlihatkan mekanisme ALV masuk ke sitoplasma, sebagai contoh adalah asam asetat. Asam asetat melewati membran sel dalam bentuk tidak terdisosiasi dan berdisosiasi dalam sitoplasma.

Penelitian ini bertujuan untuk mengidentifikasi

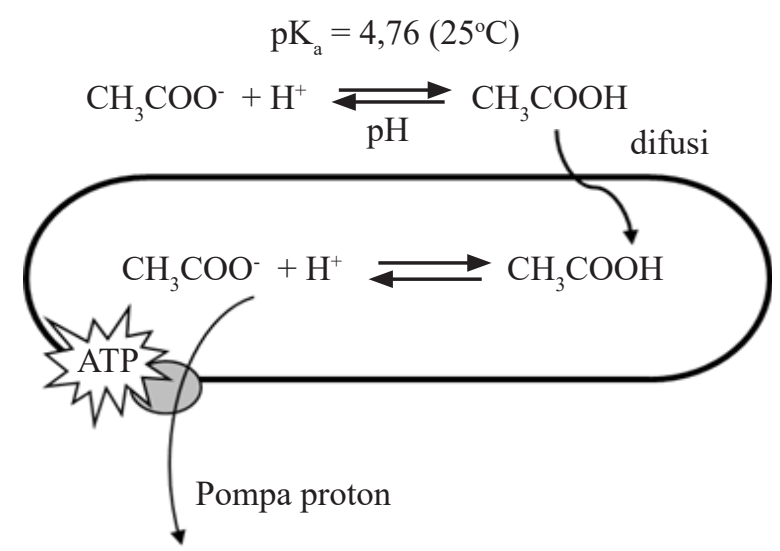

Gambar 1. Mekanisme aktivitas bakteriostatik dari asam lemak rantai pendek (sebagai contoh asam asetat) (Defoirdt et al., 2009)

komposisi dan konsentrasi ALV dari hasil fermentasi anaerobik air limbah industri minyak kelapa sawit, menentukan prosedur penambahan ALV pada waktu yang tepat untuk proses produksi PHA dengan fermentasi Ralstonia eutropha JMP 134 secara batch, dan mendapatkan produktivitas PHA dengan fermentasi Ralstonia eutropha JMP 134 secara batch.

\section{Bahan dan Metode}

\section{Bahan dan Alat}

Bahan utama yang digunakan dalam percobaan adalah glukosa (teknis, Brataco, Indonesia), air limbah industri minyak kelapa sawit diambil dari PT. Mitra Ogan Sumatera Selatan, Ralstonia eutropha JMP134 dari Joint Genome Institute USA, Asam asetat (pro analis, JT Baker, Amerika Serikat), asam propionat (pro analis, Merck, Jerman), dan asam butirat (pro analis, SigmaAldrich, Jerman).

Alat-alat yang digunakan selama penelitian adalah Erlenmeyer (Pyrex), pengukur titik leleh (Fisher-John melting point apparatus (Fischer scientific, UK)), pH meter (Jenco Electronic LTD, USA), spektrofotometer UV-VIS (Genesys 10 UV-Visible, Rochester USA), oven (Memmert, Jerman), peralatan analisis Nitrogen; alat Büchi (Büchi 412 scrubber, Büchi 435 digestion unit, Büchi 339 distilation unit, Jerman), kromatografi gas (GC-FID, Hewlett-Packard 5890 Seri II), peralatan High Performance Liquid Chromatography (HPLC) (Waters, Amerika Serikat). 


\section{Kultivasi Ralstonia eutropha JMP 134}

Ralstonia eutropha JMP 134 ditumbuhkan menggunakan medium Luria-Bertani (LB) cair yang mana mengandung $10 \mathrm{~g}$ Bacto tryptone, 5 $\mathrm{g}$ bacto yeast extract, dan $10 \mathrm{~g} \mathrm{NaCl}$ untuk $1 \mathrm{~L}$ medium. Proses reaksi dilakukan pada suhu $30^{\circ} \mathrm{C}$, $150 \mathrm{rpm}$ selama 20 jam.

\section{Fermentasi Ralstonia eutropha JMP 134}

Dua percobaan yang terpisah yaitu fermentasi anaerobik dan aerobik. Pertama adalah fermentasi anaerobik dengan sumber substrat dari air limbah industri minyak kelapa sawit dengan mikroorganisme campuran (mixed culture). Kemudian hasil fermentasi anaerobik didistilasi sebagai proses pengolahan awal (pretreatment). Fermentasi anaerobik ini ditujukan untuk menghasilkan asam lemak volatil. Proses ke dua adalah mencari kondisi operasi pada fermentasi aerobik dengan mikroba Ralstonia eutropha JMP 13 menambahkan ALV secara batch dengan waktu tertentu untuk memproduksi PHA.

Air limbah industri minyak kelapa sawit membutuhkan bibit mikroba aktif sebagai stater dalam proses fermentasi. Bibit mikroba aktif diperoleh dari proses aklimatisasi bakteri selama 3 bulan. Selanjutnya bibit mikroba aktif dapat digunakan untuk fermentasi anaerobik air limbah industri kelapa sawit. Pada penelitian ini Ralstonia eutropha JMP 134 digunakan sebagai mikroba aktif untuk membantu proses fermentasi. Komposisi medium untuk proses fermentasi dibagi menjadi 3 bagian. Larutan pertama terdiri dari 40 $\mathrm{g} / \mathrm{L}$ glukosa, $1,5 \mathrm{~g} / \mathrm{L} \mathrm{KH}_{2} \mathrm{PO}_{4}, 4 \mathrm{~g} / \mathrm{L} \mathrm{Na}_{2} \mathrm{PO}_{4}, 0,51$ $\mathrm{g} / \mathrm{L} \mathrm{MgSO}_{4} \cdot 7 \mathrm{H}_{2} \mathrm{O}$, dan $0.02 \mathrm{~g} / \mathrm{L} \mathrm{CaCl}_{2}$. Larutan kedua adalah larutan urea $(1 \mathrm{~g} / \mathrm{L})$, dan yang terakhir merupakan $10 \mathrm{ml} / \mathrm{L}$ larutan trace element yang terdiri dari $0,2 \mathrm{mg} / \mathrm{L} \mathrm{FeSO}_{4} \cdot 7 \mathrm{H}_{2} \mathrm{O}, 1,3 \mathrm{mg} / \mathrm{L}$ $\mathrm{ZnSO}_{4} \cdot 7 \mathrm{H}_{2} \mathrm{O}, 0,6 \mathrm{mg} / \mathrm{L} \mathrm{H}_{3} \mathrm{BO}_{3}$, dan $0,6 \mathrm{mg} / \mathrm{L}$ $\left(\mathrm{NH}_{4}\right)_{6} \mathrm{Mo}_{7} \mathrm{O}_{24}$. Semua larutan disterilisasi pada temperatur $121{ }^{\circ} \mathrm{C}$ dan kemudian dicampurkan dengan inoculum secara aseptik. Proses fermentasi dilakukan dengan kecepatan pengadukan sebesar $150 \mathrm{rpm}$, temperatur $30{ }^{\circ} \mathrm{C}$ pada $\mathrm{pH} 7$ selama 20 jam dalam Erlenmeyer 2 L. Hasil fermentasi kemudian didistilasi untuk mendapatkan ALV.

Pada prosedur untuk menganalisis pengaruh penambahan ALV sintetik terhadap proses fermentasi dengan Ralstonia eutropha JMP 134, percobaan dilakukan dengan menambahkan 0,25 LALV sintetik yang terdiri dari $6,6 \mathrm{~g} / \mathrm{L}$ asam asetat dan $1,2 \mathrm{~g} / \mathrm{L}$ asam propionat pada enam tempuhan dengan waktu pemberian $0,10,20,30,40$ jam dan tanpa penambahan ALV sintetik.

\section{Prosedur Analisis}

Metode analisis dilakukan untuk mengetahui berat sel kering Ralstonia eutropha JMP134 yaitu dengan dianalisis pertumbuhan sel menggunakan densitas optik dalam medium kultur pada panjang gelombang $600 \mathrm{~nm}$ dengan spektrofotometer (Genesys 10 UV-Visible, Rochester USA). Analisis COD dilakukan dengan metode dikromat (APHA, 1999). Analisis kandungan nitrogen total menggunakan metode Kjeldahl. Analisis ALV dilakukan secara titrimetri (APHA, 1999) dan HPLC (Hamzah et al., 2019) dengan tiga kali pengukuran dan analisis kandungan PHA ditentukan berdasarkan pengamatan titik leleh PHA dan metode asam krotonat (Law and Slepecky, 1961).

\section{Hasil dan Pembahasan}

\section{Identifikasi Senyawa ALV dari Air Limbah Industri Minyak Kelapa Sawit}

Air limbah industri minyak kelapa sawit memiliki bentuk yang kompleks sehingga tidak dapat digunakan secara langsung oleh Ralstonia eutropha JMP 134 dalam sintesis PHA. Fermentasi air limbah industri minyak kelapa sawit secara anaerob menggunakan kultur campuran, sehingga menghasilkan produk yang dapat digunakan dalam fermentasi PHA. Produk utama yang digunakan dari hasil fermentasi ini adalah asam lemak volatil (ALV). Analisis pada fermentasi anaerob air limbah industri minyak kelapa sawit meliputi kadar COD, MLSS, ALV, dan $\mathrm{pH}$.

Pengukuran COD pada fermentasi air limbah industri minyak kelapa sawit untuk seluruh variasi waktu fermentasi terlihat pada Gambar 2. Kadar COD awal sebelum perlakuan sebesar $35.196 \mathrm{mg} / \mathrm{L}$. Setelah fermentasi 1 hari, kadar COD sedikit menurun menjadi $33.966 \mathrm{mg} / \mathrm{L}$ atau penyisihan sebesar 3,5\%. Kadar COD untuk waktu fermentasi 2 hari dan 3 hari tidak jauh berbeda, yaitu $31.443 \mathrm{mg} / \mathrm{L}$ dan $30.602 \mathrm{mg} / \mathrm{L}$. Waktu fermentasi yang lebih lama, yaitu 4 hari memiliki kadar COD akhir $28.919 \mathrm{mg} / \mathrm{L}$ atau penyisihan sebesar $17,8 \%$. Semakin lama waktu fermentasi, maka kadar COD semakin menurun. 


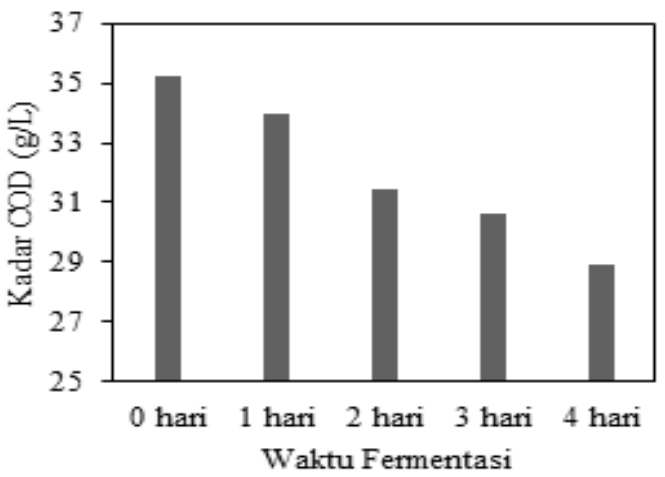

Gambar 2. Pengukuran COD air limbah industri minyak kelapa sawit

Penurunan ini disebabkan komponen organik atau sumber karbon dalam limbah tersebut digunakan oleh mikroba untuk pertumbuhan sel.

Pengamatan pertumbuhan mikroba dinyatakan sebagai kadar MLSS. Hasil pengukuran MLSS untuk tiap waktu fermentasi terlihat pada Gambar 3. Kadar MLSS awal sebelum fermentasi sebesar $2.141 \mathrm{mg} / \mathrm{L}$. Peningkatan kadar MLSS terjadi pada waktu fermentasi 1 hari dan 3 hari, yaitu sebesar $2.543 \mathrm{mg} / \mathrm{L}$ dan $2.650 \mathrm{mg} / \mathrm{L}$. Pada waktu fermentasi 2 hari dan 4 hari, kadar MLSS menurun menjadi $2.246 \mathrm{mg} / \mathrm{L}$ dan $1.947 \mathrm{mg} / \mathrm{L}$. Semakin besar kadar MLSS menunjukkan pertumbuhan populasi mikroba dalam limbah semakin banyak. Hal tersebut akan berpengaruh terhadap pengurangan kandungan sumber karbon yang terdapat dalam limbah. Penyisihan COD biasanya terjadi selama proses fermentasi dengan penyisihan COD yang tinggi digunakan dalam generasi dan sintesis sel bakteri baru untuk jalur anabolisme.

Berdasarkan Gambar 2 dan Gambar3, penurunan kadar COD tidak disertai dengan peningkatan kadar MLSS, tetapi bervariasi untuk waktu fermentasi yang lebih lama. Kemungkinan komponen organik dalam limbah tidak seluruhnya digunakan untuk pertumbuhan mikroba, tetapi untuk menghasilkan produk lain. Selama fermentasi anaerob, substrat yang mengandung karbohidrat tinggi akan menghasilkan produk asam lemak volatil (ALV), hidrogen, karbondioksida, dan terkadang alkohol (Tiang, Nordin and Abdul, 2020).

Produk utama yang dihasilkan dari fermentasi ini adalah ALV. Gambar 4 menunjukkan hasil pengukuran kadar ALV. Kadar ALV sebelum perlakuan sebesar $8.942 \mathrm{mg} / \mathrm{L}$, setelah fermentasi 1 hari jumlahnya meningkat menjadi 10.082 mg/L. Pada fermentasi 2 hari dan 3 hari kadar

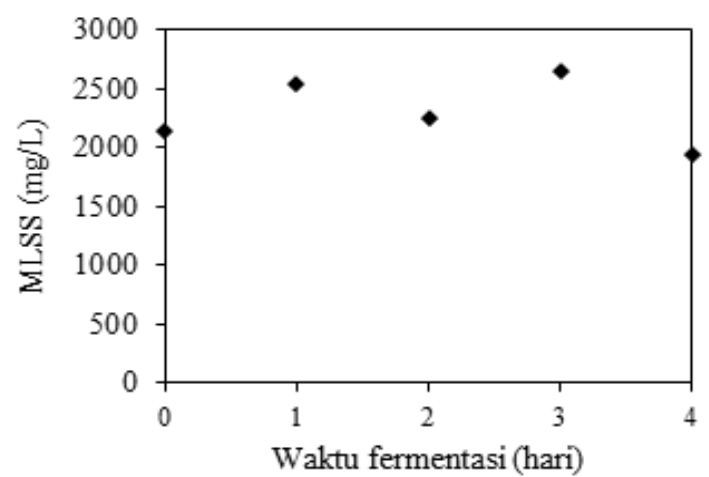

Gambar 3. Pengukuran MLSS air limbah industri minyak kelapa sawit

ALV hampir sama, yaitu $9.863 \mathrm{mg} / \mathrm{L}$ dan $9.766 \mathrm{mg} / \mathrm{L}$. Waktu fermentasi yang lama akan menurunkan kadar asam lemak volatil yang dihasilkan. Terlihat dari waktu fermentasi 4 hari memiliki kadar ALV yang paling sedikit, yaitu $8.978 \mathrm{mg} / \mathrm{L}$.

Fermentasi anaerob diaplikasikan sebagai perlakuan awal untuk mengkonversi berbagai komponen asam organik menjadi ALV yang meningkatkan potensi untuk memproduksi PHA dari limbah cair. Hidrolisis dan asidogenesis merupakan tahap awal untuk memproduksi asam organik, seperti asam asetat, propionat, dan butirat yang dapat dipergunakan untuk sintesis PHA. Proses hidrolisis komponen organik kompleks dalam air limbah industri minyak kelapa sawit menghasilkan senyawa yang lebih terlarut. Melalui proses asidogenesis, senyawa tersebut terurai menjadi ALV dan monomer lainnya. Mikroba asidogenesis dapat menghasilkan campuran larutan asam yang terdiri dari asam asetat dan asam propionat atau asam asetat dan asam butirat (Huang et al., 2020).

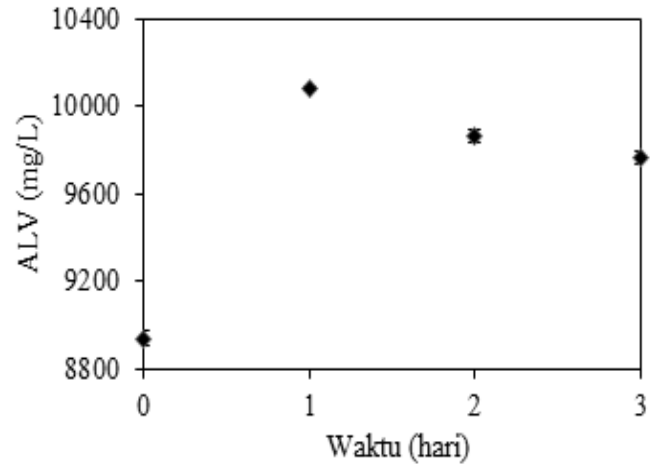

Gambar 4. Konsentrasi ALV dari hasil fermentasi air limbah industri minyak kelapa sawit secara anaerobik 
Kadar asam yang dihasilkan dalam air limbah industri minyak kelapa sawit berkorelasi dengan nilai $\mathrm{pH}$. Hasil pengukuran nilai $\mathrm{pH}$ terlihat pada Gambar 5. Nilai $\mathrm{pH}$ awal air limbah sebelum fermentasi adalah 6,2. Setelah fermentasi 1 hari nilai $\mathrm{pH}$ nya menurun menjadi 4,46 . Pada hari ke 2 nilai $\mathrm{pH}$ naik menjadi 4,9 , kemudian pada hari ke 3 terjadi kenaikan $\mathrm{pH}$ menjadi 5,9. Semakin lama waktu fermentasi, maka kadar asam lemak volatil semakin menurun. Hal ini mengakibatkan nilai $\mathrm{pH}$ cenderung meningkat ketika waktu fermentasi dilakukan lebih lama.

Data hasil fermentasi anaerob air limbah industri minyak kelapa sawit menunjukan bahwa waktu terbaik untuk memproduksi ALV adalah 1 hari, karena asam yang dihasilkan cukup tinggi, yaitu sekitar $10.082 \mathrm{mg} / \mathrm{L}$ atau $10 \mathrm{~g} / \mathrm{L}$. Konsentrasi ALV yang digunakan pada percobaan ini hampir sama dengan kandungan asam dalam larutan air limbah industri minyak kelapa sawit pada fermentasi batch, yaitu $5212 \pm 505 \mathrm{mg} / \mathrm{L}$ (Tiang, Nordin and Abdul, 2020).

Konsentrasi ALV dari air limbah industri kelapa sawit sebelum dan setelah fermentasi mengalami kenaikan, masing-masing untuk asam asetat, propionat dan butirat yaitu 52\%, 46\% dan 90\%. Kenaikan konsentrasi ALV setelah fermentasi ini disebabkan adanya fermentasi asidogenik dengan tahapan awal melalui proses hidrolisis. Fermentasi anaerobik diawal adanya proses hidrolisis berperan untuk mendegradasi senyawa organik komplek yang berupa polimer menjadi monomer dilakukan oleh mikroba hidrolitik. Mikroba ini berperan merubah lipida menjadi asam lemak rantai panjang, gliserin, dan polisakarida menjadi gula (mono dan disakarida), seperti yang ditunjukkan pada Persamaan 1 dan Persamaan 2. Selanjutnya monomer-

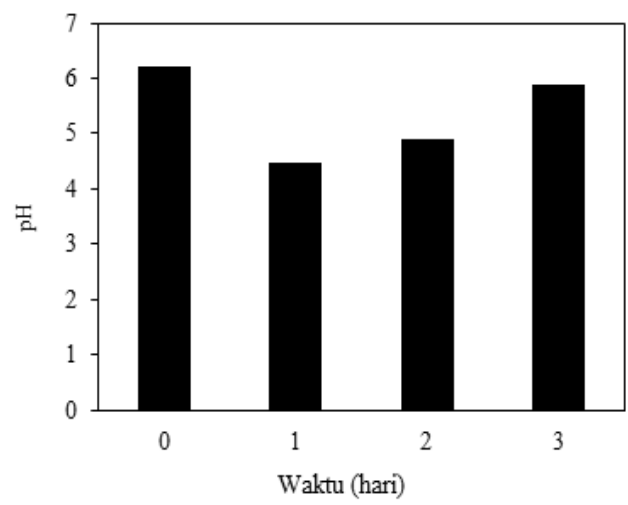

Gambar 5. Perubahan $\mathrm{pH}$ air limbah industri minyak kelapa sawit terhadap waktu fermentasi monomer hasil hidrolisis dirubah melalui proses asidogenesis yang akan dikonversi oleh bakteri asidogenik. Hasil konversi dari gula sederhana dan asam lemak menjadi senyawa organik sederhana, seperti asam lemak volatil, asam laktat, karbondioksida, dan hidrogen, yang diperlihatkan pada Persamaan 3 sampai Persamaan 6 (Seadi et al., 2016).

\section{- Hidrolisis}

Polisakarida $\rightarrow$ monosakarida

Lipid $\rightarrow$ asam lemak, gliserol

- Asidogenesis

$\mathrm{C}_{6} \mathrm{H}_{12} \mathrm{O}_{6} \rightarrow 2 \mathrm{CH}_{3} \mathrm{CHOHCOOH}$ (asam laktat) $\ldots$ (3)
$\mathrm{C}_{6} \mathrm{H}_{12} \mathrm{O}_{6} \rightarrow \mathrm{CH}_{3} \mathrm{CH}_{2} \mathrm{CH}_{2} \mathrm{COOH}+2 \mathrm{CO}_{2}+2 \mathrm{H}_{2}$ (asam
butirat)
$\mathrm{C}_{6} \mathrm{H}_{12} \mathrm{O}_{6} \rightarrow \mathrm{CH}_{3} \mathrm{CH}_{2} \mathrm{COOH}+2 \mathrm{CO}_{2}$ (asam propionat)
$\mathrm{C}_{6} \mathrm{H}_{12} \mathrm{O}_{6}+2 \mathrm{H}_{2} \mathrm{O} \rightarrow \mathrm{CH}_{3} \mathrm{COOH}+4 \mathrm{H}_{2}$ (asam asetat)

Persamaan reaksi asidogenesis ini memperlihatkan dari hasil yang pemingkatan konsentrasi ALV setelah fermentasi. Peningkatan ALV disebabkan adanya perubahan dari polimer yang ada pada air limbah industri kelapa sawit yang didegradasi oleh bakteri hidrolisat dan selanjutnya oleh bakteri asidogenik dirubah menjadi senyawa ALV.

Nilai $\mathrm{pH}$ fermentasi mempengaruhi konsentrasi dan komposisi ALV dari air limbah industri minyak kelapa sawit (Tiang, Nordin and Abdul, 2020). Fermentasi air limbah industri minyak kelapa sawit pada $\mathrm{pH} 4$ mendapatkan asam formiat, asam asetat, dan asam propionat masing-masing bernilai 1,4 g/L, 4,4 g/L, dan 0,5 $\mathrm{g} / \mathrm{L}$, sedangkan pada $\mathrm{pH}=7$ terdiri asam asetat dan asam propionat yaitu $6,6 \mathrm{~g} / \mathrm{L}$, dan $1,2 \mathrm{~g} / \mathrm{L}$ (Mamimin et al., 2017).

Air limbah industri minyak kelapa sawit ini juga dianalisis untuk mengetahui kandungan nitrogen total. Kandungan nitrogen total yang dikandung oleh air limbah industri minyak kelapa sawit awal, setelah difermentasi dan air limbah tersebut setelah difermentasi serta didistilasi masing-masing yaitu $136,68 \mathrm{~g} / \mathrm{L}, 183,07 \mathrm{~g} / \mathrm{L}$, dan 0 g/L. Gambar 6 membandingkan kandungan nitrogen total pada berbagai tahapan operasi. Air limbah industri minyak kelapa sawit setelah distilasi menunjukkan kadar nitrogen total adalah 


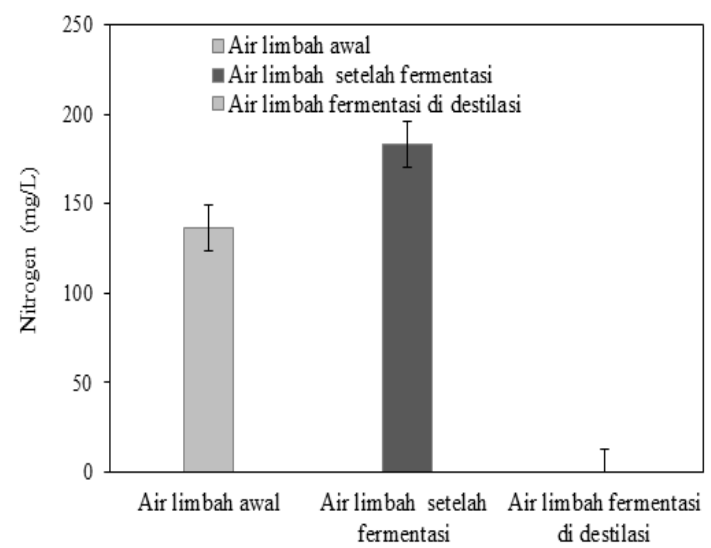

Gambar 6. Perbandingan kandungan nitrogen total $(\mathrm{g} / \mathrm{L})$ pada air limbah industri minyak kelapa sawit awal, air limbah industri minyak kelapa sawit setelah fermentasi, dan air limbah industri minyak kelapa sawit setelah fermentasi dan destilasi

$0 \mathrm{~g} / \mathrm{L}$ dan hanya mengandung ALV. ALV dari hasil distilasi tersebut yang akan digunakan sebagai prekursor dalam fermentasi untuk memproduksi PHA. Konsentrasi ALV hasil distilasi terdiri dari asam asetat, asam propionat, dan asam butirat yang masing-masing bernilai $2,79 \mathrm{~g} / \mathrm{L} ; 1,18 \mathrm{~g} / \mathrm{L}$; dan 3,04 g/L. Konsentrasi ALV ini digunakan sebagai dasar pembuatan larutan ALV sintetik. ALV sintetik ini digunakan sebagai pembanding dengan ALV dari air limbah industri minyak kelapa sawit.

\section{Pengaruh Waktu Pengumpanan ALV Sintetik pada Pertumbuhan Ralstonia eutropha JMP 134}

Terdapat enam tempuhan dengan waktu pengumpanan ALV sintetik sebanyak 0,25 L secara langsung masing-masing pada jam yang berbeda-beda yaitu jam ke-0 (dari awal telah diberikan ALV sintetik), ke-10, ke-20, ke-30, ke-40, dan tanpa pengumpanan ALV sintetik seperti yang telah disajikan pada Gambar 7 menunjukkan pengaruh waktu pengumpanan prekursor ALV sintetik pada pertumbuhan Ralstonia eutropha JMP 134.

Pada percobaan dengan penambahan ALV pada jam ke-0 terbentuknya konsentrasi BKS tertinggi dicapai pada jam ke-20, yaitu sebesar $0,2 \mathrm{~g} / \mathrm{L}$. Kemudian konsentrasi BKS menurun pada jam ke-30 dan nilai BKS relatif tetap setelah jam ke-40 yaitu sebesar 0,08 g/L. Pengumpanan ALV pada jam ke-10, memperlihatkan bahwa konsentrai pada jam ke-10 adalah 1,73 g/L, kemudian BKS mengalami penurunan yang terus menerus, sehingga mencapai nilai yang relatif rendah yaitu $0,32 \mathrm{~g} / \mathrm{L}$ setelah jam ke70. Penambahan ALV pada jam ke-0 dan ke10 menunjukkan sel tidak dapat tumbuh dan menyebabkan kematian. Sel belum mampu untuk menerima ALV di dalam metabolisme sel mengakibatkan ALV bertindak sebagai inhibitor dalam pertumbuhan sel.

Pemberian ALV pada jam ke-20 dan seterusnya (tempuhan III, IV, V, dan VI) tidak memperlihatkan adanya inhibisi. Hal ini tampak dari pertumbuhan sel yang mengalami peningkatan seiring dengan waktu fermentasi. Konsentrasi berat kering sel (BKS) tertinggi masing-masing tempuhan III, IV, V, dan VI adalah 6,67 g/L; 5,6 g/L; 5,13 g/L; dan 5,87 g/L.

Data-data sel pada tempuhan I dan tempuhan II menunjukkan bahwa sel belum mencapai fase pertumbuhan cepat. ALV sintetik yang ditambahkan diawal fermentasi menyebabkan aktivitas metabolik menurun atau mungkin terjadi kematian sel. Disamping itu nilai $\mathrm{pH}$ lingkungan memiliki dampak penting yang dapat menyebabkan ALV mampu masuk ke dalam sel secara difusi (Chen et al., 2013).

Gambar 8 menunjukkan bahwa waktu penambahan ALV akan mempengaruhi $\mathrm{pH}$ medium. Penambahan ALV pada tempuhan I dan II menyebabkan $\mathrm{pH}$ medium turun dari $\mathrm{pH}$ 7 menjadi $\mathrm{pH}$ 4,5. Pada fermentasi tempuhan I dan II, jumlah ALV tidak terdisosiasi yang dapat masuk ke dalam sitoplasma semakin besar dikarenakan terdapat perbedaan gradien antara $\mathrm{pH}$ lingkungan dan sitoplasma sel (Cerrone et al., 2014). Pada tempuhan VI (tanpa ALV) penurunan $\mathrm{pH}$ terjadi secara perlahan-lahan yaitu dari $\mathrm{pH} 7$ menjadi $\mathrm{pH}$ 5,5. Penurunan ini disebabkan pada tempuhan VI dihasilkan asam sebagai produk fermentasi secara alami. Nilai pH medium pada tempuhan III, IV, dan $\mathrm{V}$ mengalami penurunan yang mendekati sama dengan tempuhan VI. Dengan demikian diduga bahwa sel pada tempuhan III, IV, dan V mampu mengkonsumsi asam untuk pertumbuhannya. Sel membutuhkan sumber karbon lain ketika substrat glukosa mulai habis. Hal ini menyebabkan waktu pengumpanan ALV perlu dipersiapkan dengan seksama untuk menjaga $\mathrm{pH}$ fisiologis dari medium fermentasi. ALV akan mempengaruhi fisiologis sel dikarenakan kondisi asam dalam medium pertumbuhan. 


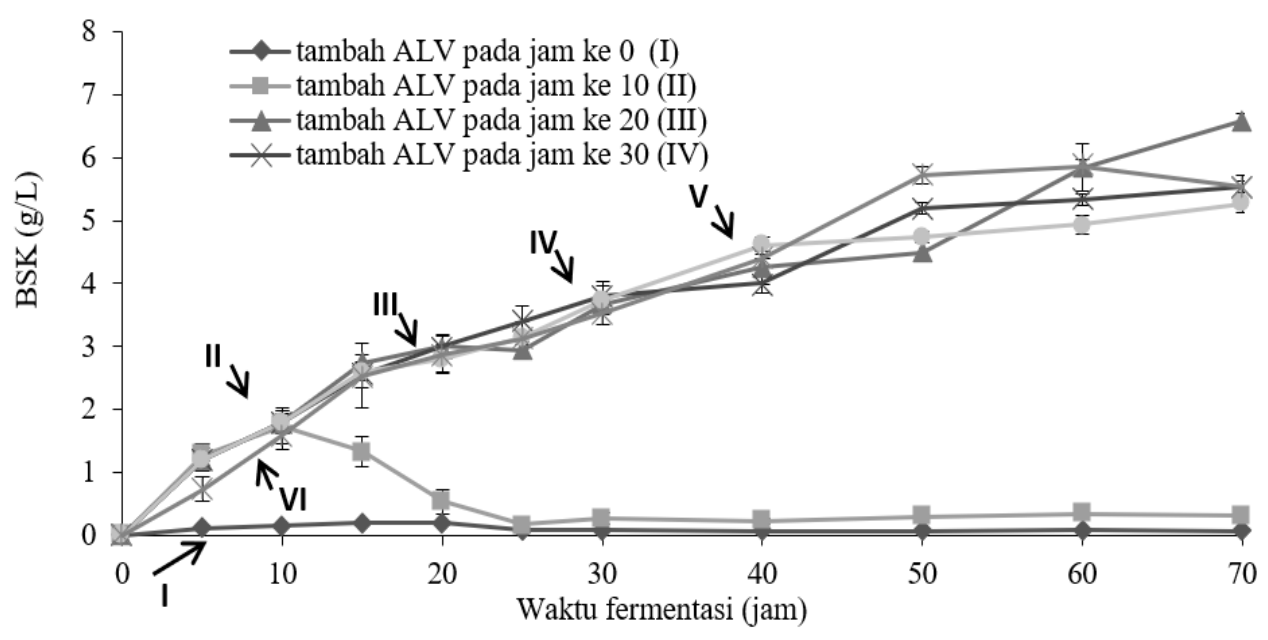

Gambar 7. Pengaruh waktu pengumpanan ALV sintetik pada pertumbuhan Ralstonia eutropha JMP 134 sebagai fungsi waktu fermentasi (jam) dan BKS (g/L). Konsentrasi glukosa $=40 \mathrm{~g} / \mathrm{L}$, konsentrasi ALV sintetik (asam asetat dan asam propionat adalah $6,6 \mathrm{~g} / \mathrm{L}$ dan 1,2 g/L)

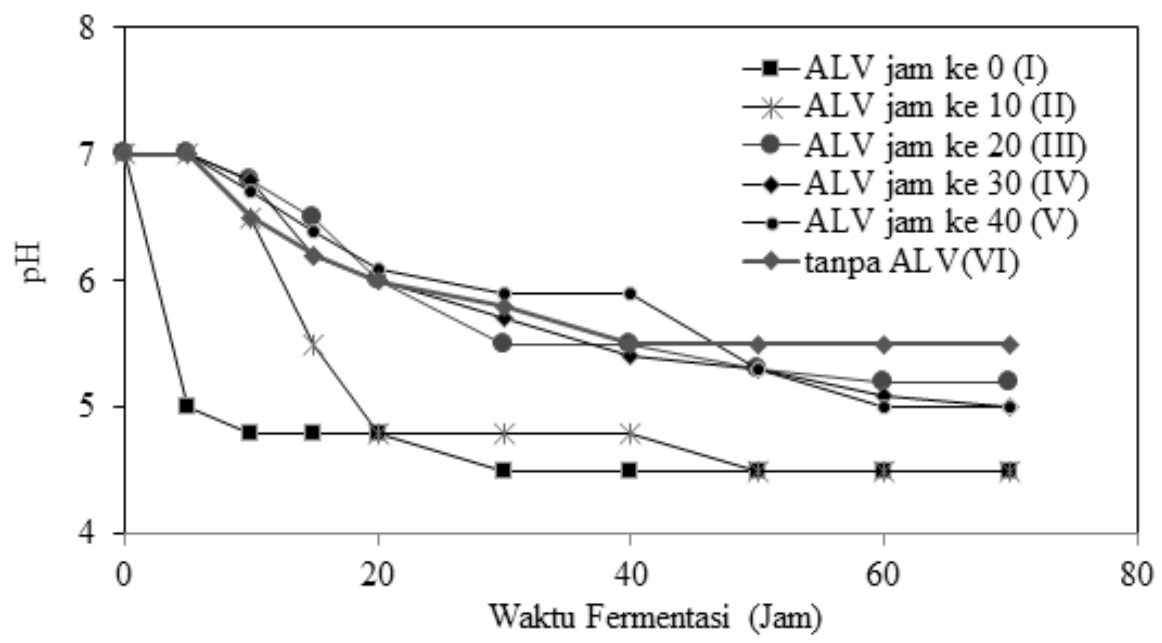

Gambar 8. Pengaruh waktu pengumpanan ALV terhadap $\mathrm{pH}$ sebagai fungsi waktu fermentasi

Penambahan ALV pada tempuhan III, IV, dan $\mathrm{V}$ menunjukkan turunnya konsentrasi BKS, segera setelah ditambahkan ALV. Penurunan konsentrasi BKS disebabkan sel mengalami proses adaptasi terhadap sumber karbon dari ALV. Setelah tahapan adaptasi maka jumlah sel mengalami peningkatan kembali. Fermentasi sel pada tempuhan III, IV, dan V mempunyai konsentrasi BKS tertinggi masing-masing sebesar $6,68 \mathrm{~g} / \mathrm{L}, 5,53 \mathrm{~g} / \mathrm{L}$, dan $5,27 \mathrm{~g} / \mathrm{L}$ yang dicapai pada jam ke-70. Data-data ini menunjukkan sel dapat beradaptasi dan berkembang dengan prekursor ALV. Sel pada fase pertumbuhan cepat mempunyai kemampuan memproduksi energi dan komponen-komponen yang telah terintegrasi. Sel mempunyai kemampuan untuk mengkonsumsi ALV setelah sel mengalami fase pertumbuhan cepat (Setiadi et al., 2015). Data-data pada tempuhan III, IV dan V menunjukkan ALV tidak menghambat atau menyebabkan kematian sel. Pengaruh waktu penambahan ALV sintetik dapat mempengaruhi pertumbuhan ataupun kematian sel tersebut.

\section{Perbandingan Produksi PHA dari Prekursor dari ALV Sintetik atau ALV dari Air Limbah Industri Minyak Kelapa Sawit}

Tabel 1. menunjukkan perbandingan kandungan PHA terhadap waktu fermentasi pada 
berbagai variasi penambahan ALV. Fermentasi dengan ALV dari air limbah industri minyak kelapa sawit ditambahkan pada jam ke-40 dan 60 mempunyai kandungan PHA lebih kecil dari percobaan lainnnya yaitu $0,38 \mathrm{~g}$ PHA/g BKS. Kandungan PHA yang didapat menggunakan ALV dari air limbah industri minyak kelapa sawit dari penambahan pada jam ke-20 dan 40 adalah $0,75 \mathrm{~g} \mathrm{PHA} / \mathrm{g}$ BKS.

Fermentasi dengan ALV sintetik yang diberikan pada jam ke-20 dan 40 menghasilkan $0,74 \mathrm{~g}$ PHA/g BKS, selama fermentasi $200 \mathrm{jam}$. Khardenavis et al. (2005) mengerjakan fermentasi air limbah sintetik secara batch selama 96 jam yang menghasilkan 0,66 g PHA/g BKS. Dari berbagai penelitian memperlihatkan bahwa kandungan PHA yang didapat tergantung pada substrat ALV sebagai prekursor, waktu penambahan ALV dan lamanya waktu fermentasi. Disamping itu, mode kultivasi juga akan sangat menentukan jumlah sel yang tumbuh dan akan mempengaruhi kandungan PHA. Perbandingan dari ketiga variabel waktu penambahan ALV sintetik dan ALV dari air limbah industri minyak kelapa sawit terhadap laju konsumsi substrat, laju konsumsi ALV, yield sel, yield PHA, dan kandungan PHA disajikan pada Tabel 2. Perbandingan laju rata-rata konsumsi glukosa menunjukkan hasil yang sama antara ketiga variabel tersebut. Ralstonia eutropha JMP 134 membutuhkan glukosa untuk fase pertumbuhan.

Tabel 1. Perbandingan kandungan PHA dari Prekursor dari ALV sintetik atau ALV dari air limbah industri minyak kelapa sawit ditambahkan secara batch

\begin{tabular}{cccc}
\hline $\begin{array}{c}\text { Waktu } \\
\text { fermentasi } \\
\text { (jam) }\end{array}$ & $\begin{array}{c}\text { Kandungan } \\
\text { PHA }^{\mathrm{a}}\end{array}$ & $\begin{array}{c}\text { Kandungan } \\
\text { PHA }^{\mathrm{b}}\end{array}$ & $\begin{array}{c}\text { Kandungan } \\
\text { PHA }^{\mathrm{c}}\end{array}$ \\
\hline 0 & 0,00 & 0,00 & 0,00 \\
20 & 0,19 & 0,19 & 0,19 \\
40 & 0,19 & 0,11 & 0,11 \\
60 & 0,14 & 0,08 & 0,10 \\
80 & 0,15 & 0,32 & 0,37 \\
100 & 0,18 & 0,36 & 0,35 \\
120 & 0,22 & 0,59 & 0,39 \\
140 & 0,58 & 0,68 & 0,45 \\
160 & 0,63 & 0,64 & 0,42 \\
180 & 0,68 & 0,69 & 0,41 \\
200 & 0,74 & 0,75 & 0,41 \\
\hline
\end{tabular}

${ }^{\mathrm{g}} \mathrm{PHA} / \mathrm{g}$ BKS ALV sintetik

${ }^{\mathrm{b}} \mathrm{g}$ PHA/g BKS ALV ${ }^{20-40}$ air limbah industri minyak kelapa sawit ${ }^{\circ} \mathrm{g}$ PHA/g BKS ALV ${ }^{40-60}$ air limbah industri minyak kelapa sawit
Produktivitas PHA dari penambahan ALV sintetik dan ALV dari air limbah industri minyak kelapa sawit pada jam ke-20 dan 40 menunjukkan masing-masing harga yang hampir sama yaitu 0,013 dan 0,014 g/L.jam, sedangkan untuk penambahan ALV pada jam ke-40 dan 60 bernilai 0,005 g. $\mathrm{L}^{-1} \cdot \mathrm{jam}^{-1}$. Hal ini menunjukkan bahwa waktu penambahan ALV sebagai prekursor sangat penting untuk meningkatkan produktivitas PHA. Nilai perolehan sel dan perolehan PHA untuk ALV dari air limbah industri minyak kelapa sawit yang ditambahkan pada jam ke-20 dan 40 mempunyai nilai lebih tinggi daripada kedua percobaan yang lain yaitu 0,10 dan 0,08. Sedangkan nilai perolehan sel dan perolehan PHA dari fermentasi dengan ALV dari air limbah industri minyak kelapa sawit yang diberikan pada jam ke-40 dan 60 mempunyai nilai yang lebih kecil dibandingkan dengan kedua variabel di atas bernilai masing-masing yaitu 0,056 dan 0,03 . ALV yang ditambahkan pada jam ke-20 dan 40 dalam produksi PHA lebih tinggi dibandingkan dengan penambahan ALV jam ke-40 dan 60 . Pada jam ke-20 dan jam ke-40, sel mengalami fase pertumbuhan cepat dan memulai produksi PHA. Dengan demikian, sel dapat beradaptasi dengan prekursor ALV sekaligus memproduksi PHA. Penambahan ALV pada jam ke-40 dan jam ke-60, sel telah mengalami kekurangan substrat glukosa pada jam ke-20, sehingga ada tenggang waktu yang relatif lama, sehingga sel sudah mengalami fase tetap mengakibatkan produksi PHA terhambat.

ALV dari air limbah industri minyak kelapa sawit sangat bermanfaat di dalam produksi PHA tetapi juga akan sangat mempengaruhi dalam pertumbuhan sel. ALV yang ditambahkan secara batch dalam fase pertumbuhan akan menghambat laju pertumbuhan sel. PHA yang terbentuk merupakan metabolisme sekunder, sehingga akan lebih baik jika digunakan metoda dengan cara fed batch. Fed batch akan meningkatkan produktivitas PHA dan juga untuk mencegah kematian Ralstonia eutropha. Oleh karena itu, ALV ditambahkan setelah sel mengalami pertumbuhan cepat dengan penambahan ALV secara perlahan-lahan. Laju alir, volume dan waktu pengumpanan ALV sangat menentukan optimalisasi produktivitas PHA.

Perbandingan laju konsumsi rata-rata ALV untuk ketiga varibel menunjukkan bahwa ALV dari air limbah industri minyak kelapa sawit lebih mudah dikonsumsi daripada ALV sintetik. Perbandingan laju produksi PHA dengan waktu 
Tabel 2. Perbandingan laju konsumsi substrat, ALV, dan produksi PHA dari prekursor dari ALV sintetik atau ALV dari air limbah industri minyak kelapa sawit ditambahkan secara batch

\begin{tabular}{lccc}
\hline \multicolumn{1}{c}{ Kriteria } & ${ }^{\mathrm{a}} \mathrm{ALV}^{20 ; 40}$ & ${ }^{\mathrm{b}} \mathrm{ALV}^{20 ; 40}$ & ${ }^{\mathrm{b}} \mathrm{ALV}^{40 ; 60}$ \\
\hline $\begin{array}{l}\text { Laju rata-rata konsumsi glukosa (g/L.jam) } \\
\text { Laju rata-rata konsumsi ALV (g/L.jam) }\end{array}$ & 0,1787 & 0,1756 & 0,1751 \\
$\bullet \quad$ Asam asetat & 0,0198 & 0,0228 & 0,0039 \\
$\bullet \quad$ Asam propionat & 0,0125 & 0,0207 & 0,0138 \\
$\bullet \quad$ Asam butirat & 0,0200 & 0,0354 & 0,0402 \\
Produktivitas PHA (g.L . $^{-1}$ am $^{-1}$ ) & 0,013 & 0,014 & 0,005 \\
Perolehan (yield) sel (C mol biomassa/mol substrat) & 0,092 & 0,10 & 0,056 \\
Perolehan (yield) PHA (C mol produk/mol substrat) & 0,069 & 0,08 & 0,03 \\
Kandungan PHA g PHA/g BKS & 0,74 & 0,75 & 0,41 \\
\hline
\end{tabular}

${ }^{\mathrm{a}}$ sintetik, ${ }^{\mathrm{b}}$ air limbah industri minyak kelapa sawit

$\mathrm{ALV}^{20 ; 40}$, penambahan ALV pada jam ke 20 dan 40

$\mathrm{ALV}^{40 ; 60}$, penambahan ALV pada jam ke 40 dan 60

penambahan ALV pada jam ke-20 dan 40 menunjukkan perbedaan. Laju produksi PHA dengan penambahan ALV dari air limbah industri minyak kelapa sawit lebih mudah diserap oleh sel untuk memproduksi PHA daripada ALV sintetik.

\section{Kesimpulan}

Asam lemak volatil (ALV) tertinggi didapat pada fermentasi anaerob selama 1 hari dan $\mathrm{pH}$ 4,43. PHA sangat ditentukan oleh waktu penambahan dan konsentrasi ALV sebagai prekursor. Produktivitas PHA, konsentrasi PHA dan BKS yang diperoleh pada penambahan ALV dari air limbah industri kelapa sawit secara batch pada jam ke-20 dan 40 masingmasing bernilai 0,014 g/L.jam, 2,76 g/L dan 3,66 g/L. Hasil analisis untuk penambahan ALV dari air limbah industri kelapa sawit pada jam ke-40 dan 60 memperlihatkan produktivitas, konsentrasi PHA dan BKS masing-masing adalah 0,005 g/L.jam, 0,917 g/L, dan 2,22 g/L.

\section{Daftar Pustaka}

APHA (1999) Standard Methods for the Examination of Water and Wastewater. 17th edn. Washington, DC: American Public Health Association, American Water Works Association, Water Pollution Control Federation. Atasoy, M., Eyice, Ö. and Cetecioglu, Z. (2020) 'Volatile fatty acid production from semisynthetic milk processing wastewater under alkali $\mathrm{pH}$ : The pearls and pitfalls of microbial culture', Bioresource Technology, 297, p. 122415. doi: 10.1016/j.biortech.2019.122415.
BPS (2018) Produksi Perkebunan Besar menurut Jenis Tanaman, Indonesia (Ton), 1995 - 2018. Available at: http://www.bps.go.id (Accessed: 4 September 2020).

Cerrone, F., Choudhari, S. K., Davis, R., Cysneiros, D., O'Flaherty, V., Duane, G., Casey, E., Guzik, M. W., Kenny, S. T., Babu, R. P. and O'Connor, K. (2014) 'Medium chain length polyhydroxyalkanoate (mcl-PHA) production from volatile fatty acids derived from the anaerobic digestion of grass', Applied Microbiology and Biotechnology, 98(2), pp. 611-620. doi: 10.1007/s00253-013-5323-x.

Chen, H., Meng, H., Nie, Z. and Zhang, M. (2013) 'Polyhydroxyalkanoate production from fermented volatile fatty acids: Effect of $\mathrm{pH}$ and feeding regimes', Bioresource Technology, 128, pp. 533-538. doi: 10.1016/j. biortech.2012.10.121.

Chinwetkitvanich, S. and Jaikawna, H. (2015) 'Volatile Fatty Acids (VFAs) production from Palm Oil Mill Effluent (POME) fermentation', in Chan, D. (ed.) Environmental Science and Information Application Technology. CRC Press. doi: 10.1201/b18559-27.

Defoirdt, T., Boon, N., Sorgeloos, P., Verstraete, W. and Bossier, P. (2009) 'Short-chain fatty acids and poly- $\beta$-hydroxyalkanoates: (New) Biocontrol agents for a sustainable animal production', Biotechnology Advances, 27(6), pp. 680-685. doi: 10.1016/j. biotechadv.2009.04.026.

Hamzah, M. A. F., Jahim, J. M., Abdul, P. M. and Asis, A. J. (2019) 'Investigation of Temperature Effect on Start-Up Operation from Anaerobic Digestion of Acidified Palm Oil Mill Effluent', Energies, 12(13), p. 2473. doi: 10.3390/en12132473. 
Huang, L., Chen, Z., Wen, Q., Ji, Y., Wu, Z. and Lee, D.-J. (2020) 'Toward flexible regulation of polyhydroxyalkanoate composition based on substrate feeding strategy: Insights into microbial community and metabolic features', Bioresource Technology, 296, p. 122369. doi: 10.1016/j.biortech.2019.122369.

Koller, M. (2018) 'A Review on Established and Emerging Fermentation Schemes for Microbial Production of Polyhydroxyalkanoate (PHA) Biopolyesters', Fermentation, 4(2), pp. 1-30. doi: $10.3390 /$ fermentation 4020030 .

Law, J. H. and Slepecky, R. A. (1961) 'Assay of poly- $\beta$-hydroxybutyric acid', Journal of Bacteriology, 82(1), pp. 33-36. doi: 10.1128/ jb.82.1.33-36.1961.

Lee, W. S., Chua, A. S. M., Yeoh, H. K. and Ngoh, G. C. (2014) 'Influence of temperature on the bioconversion of palm oil mill effluent into volatile fatty acids as precursor to the production of polyhydroxyalkanoates', Journal of Chemical Technology \& Biotechnology, 89(7), pp. 1038-1043. doi: 10.1002/jctb.4197.

Mamimin, C., Prasertsan, P., Kongjan, P. and O-Thong, S. (2017) 'Effects of volatile fatty acids in biohydrogen effluent on biohythane production from palm oil mill effluent under thermophilic condition', Electronic Journal of Biotechnology, 29, pp. 78-85. doi: 10.1016/j. ejbt.2017.07.006.

Meereboer, K. W., Misra, M. and Mohanty, A. K. (2020) 'Review of recent advances in the biodegradability of polyhydroxyalkanoate (PHA) bioplastics and their composites', Green Chemistry, 22(17), pp. 5519-5558. doi: 10.1039/D0GC01647K.

Oliveira, G. H. D., Zaiat, M., Rodrigues, J. A. D., Ramsay, J. A. and Ramsay, B. A. (2020) 'Towards the Production of mcl-PHA with Enriched Dominant Monomer Content: Process Development for the Sugarcane Biorefinery Context', Journal of Polymers and the Environment, 28(3), pp. 844-853. doi: 10.1007/s10924-019-01637-2.

Patel, A., Sarkar, O., Rova, U., Christakopoulos, P. and Matsakas, L. (2021) 'Valorization of volatile fatty acids derived from low-cost organic waste for lipogenesis in oleaginous microorganisms-A review', Bioresource Technology, 321, p. 124457. doi: 10.1016/j. biortech.2020.124457.
Perez-Zabaleta, M., Atasoy, M., Khatami, K., Eriksson, E. and Cetecioglu, Z. (2021) 'Biobased conversion of volatile fatty acids from waste streams to polyhydroxyalkanoates using mixed microbial cultures', Bioresource Technology, 323, p. 124604. doi: 10.1016/j. biortech.2020.124604.

Ramos-Suarez, M., Zhang, Y. and Outram, V. (2021) 'Current perspectives on acidogenic fermentation to produce volatile fatty acids from waste', Reviews in Environmental Science and Bio/Technology, 20(2), pp. 439478. doi: 10.1007/s11157-021-09566-0.

Seadi, T. Al, Rutz, D., Prassl, H., Köttner, M., Finsterwalder, T., Volk, S. and Janssen, R. (2016) Biogas handbook. Esbjerg, Denmark: University of Southern Denmark Esbjerg, Niels Bohrs Vej 9-10.

Setiadi, T., Aznury, M., Trianto, A. and Pancoro, A. (2015) 'Production of polyhydroxyalkanoate (PHA) by Ralstonia eutropha JMP 134 with volatile fatty acids from palm oil mill effluent as precursors', Water Science and Technology, 72(11), pp. 1889-1895. doi: 10.2166/ wst.2015.391.

Tan, G.-Y., Chen, C.-L., Li, L., Ge, L., Wang, L., Razaad, I., Li, Y., Zhao, L., Mo, Y. and Wang, J.-Y. (2014) 'Start a Research on Biopolymer Polyhydroxyalkanoate (PHA): A Review', Polymers, 6(3), pp. 706-754. doi: 10.3390/ polym6030706.

Tiang, MF., Nordin,D., Abdul, PM.,(2020), 'Effect of Feeding Strategies and Inoculums Applied on Two-Stage Biosynthesis of Polyhydroxyalkanoates from Palm Oil Mill Effluent', Journal of Polymers and the Environment, 28: 7,1934-1943.

Wang, Q. and Nomura, C. T. (2010) 'Monitoring differences in gene expression levels and polyhydroxyalkanoate (PHA) production in Pseudomonas putida KT2440 grown on different carbon sources', Journal of Bioscience and Bioengineering, 110(6), pp. 653-659. doi: 10.1016/j.jbiosc.2010.08.001.

Zhang, D., Jiang, H., Chang, J., Sun, J., Tu, W. and Wang, H. (2019) 'Effect of thermal hydrolysis pretreatment on volatile fatty acids production in sludge acidification and subsequent polyhydroxyalkanoates production', Bioresource Technology, 279, pp. 92-100. doi: 10.1016/j.biortech.2019.01.077. 